decided to inter the deceased's remains in order that she would 'have somewhere to visit him and feel close to him'. She was not made aware that the land in question was consecrated. The chancellor distinguished this case from that of a simple 'change of mind', stating that the widow's change of mind arose not from a passing fancy but rather from a serious wish to rectify what she realised to have been an error on her part. He found that special circumstances existed and issued a faculty accordingly. [RA]

doi:10.1017/So956618X10001067

\title{
Kings v Bultitrode and another; re Schroder
}

High Court, Chancery Division: Proudman J, July 2010

Will - charitable donation - cy-près doctrine

The claimant was a solicitor and executor of the will of Mrs S, who had been the leading member of a small independent church, the Ancient Catholic Church. The defendants were the representative of the beneficiaries in the case of partial intestacy and the Attorney General. The court found that the church to which the deceased had bequeathed her residuary estate no longer existed, largely as a result of her death, when members went their separate ways and the building, leased to the deceased, ceased to be used by them. The court held that the gift was dependent on the continued existence of the church. The residuary estate was not therefore the subject of a valid charitable gift. The specific intention of the deceased was such that the estate could not be applied $c y$-près to other charitable purposes and was therefore to be distributed under the rules of intestacy. The court further held that the property and assets of the church (rather than those of the deceased) were to be applied cy-près and were to be accounted to the Attorney General. [WA]

doi:10.1017/So956618X10001079

\section{Re Holy Trinity, Eccleshall}

Court of Arches: George, Dean; Briden and Box Chs, July 2010 Appeal - recusal of chancellor - evidence - wrong evaluation

The appellants appealed the judgment of Chancellor Coates, sitting in Lichfield Consistory Court, ${ }^{5}$ refusing to grant a faculty for the internal reordering of the 